\title{
САМОСТІЙНІСТЬ ЯК ВАЖЛИВИЙ ЧИННИК У МИСТЕЦТВІ ДИРИГУВАННЯ МАЙБУТНЬОГО ВЧИТЕЛЯ МУЗИКИ
}

Пономаренко Т. В. Самостійність як важливий чинник у мистецтві диригування майбутнього вчителя музики.

У статті автор розглядає можливість досягти високої якості мистецтва диригування не лише шляхом вироблення в процесі навчання у вищому навчальному закладі теоретичних і практичних навичок, а також у процесі самостійної роботи.

Ключові слова: хорове диригування, диригент-початківець, диригентська інформація, диригентська діяльність.

Пономаренко Т. В. Самостоятельность как важная составляющая в искусстве дирижирования будущего учителя музыки.

В статье автор рассматривает возможность достижения высокого качества в искусстве дирижирования путем овладения теоретических и практических навыков в процессе обучения в высшем учебном заведении, а также в процессе самостоятельной работы.

Ключевые слова: хоровое дирижирование, начинающий дирижер, дирижерская информация, дирижерская деятельность.

Ponomarenko T. V. Independence is an important component of art conducting of future music teachers.

The author considers the possibility of achieving the quality of the temple in the art of conducting, not only obtained in the learning process in higher education of theoretical and practical skills, but also due to work independently.

Key words: choral conducting, aspiring conductor, conductor information conductor's activity.

Українське музичне мистецтво має витоками часи Київської Русі і в своєму розвитку охоплює практично всі типи музичного мистецтва - народну і професійну, академічну і популярну музику. Нині українська музика у іiі багатомаїтті звучить в Україні та поза ії межами, вона продовжує розвиватись у народній та професійній традиціях, є предметом вивчення науковців.

Особливе місце серед виконавських мистецтв належить диригуванню, хоча до недавнього часу диригування усвідомлювалося лише як «мистецтво керування колективним виконанням музики».

Довгий час диригенти в основному підтримували ансамбль у виконанні, а виконавський колектив прагнув правильно передати нотний текст. Проте високий рівень розвитку музичного мистецтва в XVIII столітті вимагав уже не тільки правильного відтворення нотного тексту, але i його художньої інтерпретації. 3 тих пір техніка диригування спрямована не тільки на управління виконавським колективом, але й на рішення художніх задач, увібравши передовий досвід минулого.

Метою статті є доведення, що досягнення високої якості у мистецтві диригування можливе не лише на засаді здобутих теоретичних і практичних навичок у вищому навчальному закладі, але й завдяки самостійній роботі, ретроспективному аналізу та вивченню спадщини диригентської школи, а на основі цього - виокремлення своїх форм управління колективним виконанням.

Завдяки музичним навчальним закладам, українська фортепіанна та інструментальна культура здобула світове визнання. На світовий щабель піднялися й українські співаки, серед яких - С. Крушельницька, Б. Гмиря, А. Солов'яненко, Є. Мірошниченко. У консерваторіях України отримували професійну підготовку відомі симфонічні та хорові 
диригенти - С. Турчак, В. Сіренко, А. Авдієвський, С. Савчук, які створили оркестри та хорові колективи світового рівня.

Віками виховували українців у повазі та любові до рідної землі, наших культурних цінностей, у гордості за нашу країну, іiі героїчне минуле, віру у процвітання і щасливе майбутнє України. Величезна плеяда українських музикантів, серед яких Д. Бортнянський, О. Кошиць, В. Якуб'як, С. Турчак, І. Блажков, В. Гуцал, М. Колесса та багато інших представників диригентської школи, створили низку нових концертних програм, що базуються на основі української народної мелодики, класичних музичних творів, найкращих пісень українських та зарубіжних композиторів.

Ці програми стали яскравими подіями в мистецькому житті нашої країни, а виступи митців на концертах і фестивалях за кордоном сприяли зближенню і взаєморозумінню людей різних національностей, викликали повагу до України, її культури. Під керівництвом вище згаданих диригентів оркестри та хорові колективи зробили новий крок у творчому сходженні, а високий рівень їхньої виконавської майстерності, неповторний колорит і якість звучання вивели музичну культуру нашого народу на новий рівень популярності в Україні та за їі межами.

Мистецтво диригування - вимагає від людини, яка присвятила себе цій діяльності, виняткових здібностей i глибоких музично-теоретичних знань. На диригента лягає головна відповідальність за правдиве відображення ідейно-художнього задуму композитора та якість виконання [1]. Це потребує вміння діяти згідно зі своїми задумами, здатності із власної ініціативи організовувати діяльність, ставити мету, а за потреби, вносити зміни, відстоювати власні погляди, організовувати, вести за собою до реалізації мети.

Згідно з Положенням «Про організацію навчального процесу у вищих навчальних закладах» самостійна робота студента $\epsilon$ основним засобом оволодіння навчальним матеріалом у час, вільний від обов'язкових навчальних завдань. Основними функціями самостійної роботи студентів є: пізнавальна, самостійна, прогностична, коригувальна та виховна. Саме самостійну роботу ми вважаємо важливим чинником у формуванні творчої особистості диригента, майбутнього вчителя музики загальноосвітньої школи, яка обумовлена не тільки специфічними вміннями, спеціальною підготовкою, але й загальною культурою, високим інтелектуальним розвитком особистості.

Багаторічний досвід показує, що диригування $є$ загальним компонентом усіх основних напрямів професійної діяльності вчителя музики, ця діяльність певною мірою сприяє залученню підростаючого покоління до музичної культури, надає підставу розглядати його відносно самостійний напрям праці вчителя. Оволодіння знаннями, вміннями і навичками у процесі організації диригентської діяльності вчителя музики зводиться до найважливішого - вдосконалення його самостійної роботи.

У музичній енциклопедії диригент (від лат. dirigio - спрямовую, керую) - людина, яка керує підготовкою твору до виконання (проводить репетиції) та керує виконанням твору (диригує) оркестром, хором, ансамблем, зокрема оперною чи балетною трупою тощо [3, с. 175 ]. Окрім ритму диригент передає оркестру динамічні ефекти (посилення й послаблення звуку), прискорення, уповільнення і зупинки руху, а також показує, коли якому інструменту вступати. Він забезпечує ансамбль, стрункість і технічну довершеність виконання. Його завданням $є$ відтворити за допомогою керованого ним колективу виконавців свої художні наміри, розуміння твору (інтерпретація).

У спеціальній науково-методичній літературі 3 диригентської підготовки майбутнього вчителя музики багато уваги приділяється постановці рук та корпусу, опануванню так званих диригентських сіток - системи ауфтактів, оформлених у спеціальні циклічні жести, які виконують функцію показу розміру твору, початку співу (вступу), завершення співу (зняття), темпу твору, його динамічних нюансів, характеру звуковедення. Безумовно, опанування диригентських сіток потребує величезної постановчої роботи як 3 боку викладача, так і з боку студента. Але це лише технічний, формальний, хоча й важливий, бік 
диригентської практики. Постановка диригентського апарату, позбавлена художності й емоційності, - перетворюється на позбавлену життя й змісту знакову систему і виходить за рамки мистецтва.

Перше, на що слід звернути увагу студента, починаючого вивчати диригування, це різниця між тактуванням та диригуванням. Адже тактування - це «відбиття» такту, а диригування - передавання образу твору, його художнього змісту. Провідним видом підготовки студентів (особливо заочної форми навчання) $\epsilon$ самостійне опрацювання навчального матеріалу, тому завданням викладачів ВНЗ $\epsilon$ не тільки забезпечення належного рівня фахової підготовки під час лекційних і практичних занять, а й допомога в організації самостійної роботи студентів.

Із питань викладання хорового диригування в умовах педагогічних університетів на сучасному етапі обмаль необхідної літератури. У навчальній роботі викладачі музичнопедагогічних факультетів користуються переважно літературою, виданою для музичних училищ та консерваторій. Серед багатьох посібників із диригування в педагогічній практиці найчастіше використовують такі, як: «Керування хором» К. Пігрова, «Методика викладання хорового диригування» Л. Андреєвої, «Про диригування хором»К. Ольхова, «Основи техніки диригування» М. Колесси, «Нариси 3 техніки диригування хором» К. Птиці, «Теоретические основы дирижерской техники» К. Ольхова, «Техніка диригування» I. Мусіна, «Дирижерский аппарат и его постановка» С. Казачкова та інші. У цих працях розкриваються теоретичні основи диригентської майстерності, висвітлюються загальні питання диригування, приділяється велика увага техніці диригування. Безумовно, вони надають велику допомогу i викладачам музично педагогічних факультетів вищих педагогічних закладів, і студентам. Спираючись на ці та деякі інші роботи (ідеться лише про спеціальну літературу) у класі диригування студенти отримують грунтовну теоретичну та технічну підготовку 3 диригування хором. Це переважно опанування необхідними прийомами та засобами диригентської техніки, вивчення різноманітного та досить складного для диригування репертуару, гра партитури, спів хорових партій, оволодіння навичками художньої інтерпретації музичних творів тощо.

Як свідчить багаторічний педагогічний досвід роботи з майбутніми спеціалістами, ця підготовка передбачає оволодіння системою музично-теоретичних знань, методологією і методикою творчої діяльності, численними вміннями і навичками, що спираються на розвиток природних емоційно-експресивних рухів кожного студента відповідно до його індивідуальних емоційно-психологічних властивостей, а саме: формування і розвиток музично-слухових образних уявлень, що сприяють осмисленню звучання як хорового твору в цілому, так і окремих його компонентів, розкриття його змісту, структури, характеру; ознайомлення з кращими зразками народно-пісенної творчості, творчістю російських і зарубіжних композиторів різних часів, епох і стилів; уміння та навички роботи з хоровою партитурою; розвиток музичних здібностей, формування рис характеру, необхідних для практичної роботи 3 хором та концертної діяльності; отримання необхідних знань, оволодіння уміннями та навичками техніки хорового диригування; уміння самостійно працювати над хоровою партитурою; використовувати вміння i навички диригентської техніки в практичній роботі з хором.

Дослідження стану практичної роботи студентів з хором показують, що більшість студентів розпочинають роботи без відповідно розробленого плану. Значна частина студентів навіть не знає напам'ять своїх хорових творів, слабко володіє засобом вокального показу звучання хорової парти, не говорячи вже про сам характер звучання (штрих, динаміка і таке інше), недостатньою мірою працює над строєм, ансамблем, динамікою (або не дуже розуміються на цих поняттях). Від цього і робота над художнім виконанням твору приблизна та недостатня. Усе це від того, що студент не відчуває і не уявляє собі хоровий твір у художньому звучанні, до якого він повинен прагнути у своїй роботі. Адже технічні навички, набуті в класі під час диригування під фортепіано, рідко 
застосовуються при роботі з хором. Отже, на все це студент повинен звернути увагу під час самостійної роботи над хоровим твором.

Специфіка диригентського мистецтва зумовлює характер та спрямованість годин 3 самоопрацювання диригентів-учнів, оскільки диригентська спеціальність - багатопланова і потребує різноманітних форм самостійної роботи. Процес роботи над хоровим твором містить низку етапів: вивчення й аналіз нотного тексту; визначення, підбір форм і методів репетиційної роботи; добір потрібних штрихів; визначення складних епізодів тексту та методів роботи над ними; засвоєння партитури в мануальному плані; добір жестів, що відображали б музичні образи, допомагали керувати складними у технічному відношенні епізодів твору.

Самостійна робота, безперечно, пов'язана з роботою в класі, вона відображає установку викладача, а також залежить від тієї мети, яку перед собою ставить студент (чим саме йому необхідно опанувати, який різновид навичок розвинути). Чим настирливіше диригент-початківець буде знаходити мануальні засоби втілення виразних елементів музичної фрази, тим глибше він буде розуміти зміст, спостерігаючи характерні особливості фрази (твору). Лише в цьому випадку диригент-початківець зможе зробити виконання змістовним, живим і безпосереднім.

Диригент-початківець ставить перед собою вузьку мету: приготувати завдання до наступного заняття в класі. Це обмежується мануальним засвоєнням партитури. Безперечно, спілкування з виконавцями дає більше користі, але такої можливості студент не має. Для того, щоб диригент-початківець розумів завдання, що стоять перед ним у самостійній роботі, він повинен мати уявлення про зміст диригентської техніки, про те, як перетворити тактування на засіб керування виконавцями. Лише в цьому випадку він буде бачити перспективу своїх занять, усвідомлювати, яких результатів він повинен досягти.

Самостійна робота не повинна бути хаотичною, безсистемною, вона не має засновуватись на копіюванні. У самостійній роботі слід використовувати цілеспрямовані засоби засвоєння технічних та виразних прийомів диригування, застосовувати способи контролювання процесу навчання. Це також сприятиме розвитку таких якостей, як увага та спостережливість.

Студенти-музиканти вже мають досвід спостереження за слуховими й руховими відчуттями на заняттях із музичного інструменту, але в диригентському апараті задіяні інші групи м'язів, які й підлягають усвідомленню й звільненню. Використання на уроці знайомого класичного репертуару знімає напруження, пов'язане з недостатнім знанням твору. Ефект рухової свободи досягається в тому випадку, коли студент не лише констатує відчуття «тут-і-тепер», а й намагається виявити психологічну причину напруження, що сприяє усвідомленню власної «самостійності».

Природність диригентської мови, іiї опора на загальножиттєві та специфічні музичні асоціації роблять іiі зрозумілою як музикантам-професіоналам, так і малопідготовленим учасникам самодіяльних колективів, а отже - і слухачам. А це - важливо. Диригентська інформація в першу чергу адресована виконавцям; та, виходячи 3 того, що виконання твору спрямоване на сприйняття слухачами, можна зробити висновок: диригентська інформація входить і в інформацію, адресовану слухачам, а отож, зумовлює сприйняття ними.

Слухачі, як і виконавці, не лише слухають музичний твір, а й сприймають диригента: його жести, міміку. Отже, головна вимога до диригента: відповідність характеру жестів та міміки характеру музики, яка виконується. Але це повинна бути не просто рухлива ілюстрація музики, а інформація про подальше звучання, яка має мету досягти необхідної якості звучання. Тому зрозуміло, що виразність диригентських жестів та міміки не може бути самоціллю.

Формування особистості майбутнього вчителя - важливий та складний процес. Один із його аспектів - зв'язок з загальним процесом становлення творчої особистості, який спирається на загальновідому виняткову роль музичного мистецтва, яке концентрує в собі 
світ людських цінностей. Спілкування з музичним мистецтвом у вищому навчальному закладі стає шляхом становлення особистісного світосприйняття.

Предмет «Диригування» $\epsilon$ одним із важливих у системі професійної підготовки майбутніх учителів музики. Випускник вищого навчального закладу повинен бути різнобічно розвиненим музикантом, який володіє знаннями та навичками, необхідними для подальшої практичної діяльності у якості керівника хорового колективу, що потребує виховання у студентів практичних навичок диригування, вимагає не тільки роботи під керівництвом викладача, але й самостійної роботи студента.

В умовах відродження хорової культури, яка в історії національної культури $\epsilon$ визначальною традицією, питання диригентської педагогіки набувають особливого змісту. Диригентська діяльність учителя музики є складною системою, що зумовлює необхідність вивчення цілого комплексу диригентсько-хорових дисциплін. Його основу складають диригування, хоровий клас, хорознавство та хорова практика у школі.

Самостійна робота студента сприяє поглибленню і розширенню знань, формуванню інтересу до пізнавальної діяльності, оволодінню прийомами процесу пізнання, розвитку пізнавальних здібностей. Тому, на нашу думку, вона є головним чинником підвищення ефективності підготовки майбутнього вчителя музики.

\section{Література}

1. Доронюк В. Методика викладання диригування / В. Доронюк. - Івано-Франківськ, 2005. С. 32-42. 2. Ержемский Г. Л. Психология дирижирования: Некоторые вопросы исполнительства и творческого взаимодействия дирижера с музыкальным коллективом / Г. Л. Ержемский. - М. : Музыка, 1988. - 280 с. 3. Музичний енциклопедичний словник /[гол.ред. Г.В.Келдиш]. - М. : Радянська енциклопедія, 1990. - 672 с. 4. Юцевич Ю. Є. Музика. Словник-довідник / Юрій Євгенович Юцевич. - Тернопіль : «Навчальна книга - Богдан», 2003. - 275 с.

УДК 378. 011. 3 - $051:[001.89+378.147]$

В. В. Прошкін, кандидат пед. наук, доиент, Луганський наџіональний університет імені Тараса Шевченка

\section{ІНТЕГРАЦІЯ НАУКОВО-ДОСЛІДНОЇ І НАВЧАЛЬНОЇ РОБОТИ В УНІВЕРСИТЕТСЬКІЙ ПІДГОТОВЦІ МАЙБУТНІХ УЧИТЕЛІВ ЯК СУЧАСНА ПЕДАГОГІЧНА ПРОБЛЕМА}

Прошкін В. В. Інтеграція науково-дослідної і навчальної роботи в університетській підготовці майбутніх учителів як сучасна педагогічна проблема.

У статті наголошено на необхідності розроблення спеціальної педагогічної системи інтеграції університетської науки й освіти, що визначає стратегічний напрямок наукового розвитку університету й розкриває технологію покращення професійної підготовки майбутніх учителів. Установлено, що в сучасних дослідженнях недостатньо вирішено проблему максимального поєднання науки 3 навчальним процесом на всіх його етапах.

Ключові слова: інтеграція науково-дослідної й навчальної роботи, університетська підготовка, майбутній учитель.

Прошкин В. В. Интеграция научно-исследовательской и учебной работы в университетской подготовке будущих учителей как современная педагогическая проблема.

В статье отмечена необходимость разработки специальной педагогической системы интеграции университетской науки и образования, которая определяет стратегическое направление научного развития университета и раскрывает технологию улучшения профессиональной подготовки будущих учителей. Установлено, что в современных исследованиях недостаточно разрешена проблема максимального сочетания науки с учебным процессом на всех его этапах.

Ключевые слова: интеграция научно-исследовательской и учебной работы, университетская подготовка, будущий учитель. 